\title{
Spatial Variability of Rainfall Trends in Sri Lanka from 1989 to 2019 as an Indication of Climate Change
}

\author{
Niranga Alahacoon ${ }^{1,2, *}$ and Mahesh Edirisinghe ${ }^{1}$ (D) \\ 1 Department of Physics, University of Colombo, Colombo 00300, Sri Lanka; mahesh@phys.cmb.ac.lk \\ 2 International Water Management Institute (IWMI), 127, Sunil Mawatha, Pelawatte, Colombo 10120, Sri Lanka \\ * Correspondence: n.alahacoon@cgiar.org
}

Citation: Alahacoon, N.; Edirisinghe, M. Spatial Variability of Rainfall Trends in Sri Lanka from 1989 to 2019 as an Indication of Climate Change. ISPRS Int. J. Geo-Inf. 2021, 10, 84. https://doi.org/10.3390/ijgi10020084

Academic Editor: Wolfgang Kainz

Received: 31 December 2020

Accepted: 18 February 2021

Published: 19 February 2021

Publisher's Note: MDPI stays neutral with regard to jurisdictional claims in published maps and institutional affiliations.

Copyright: (c) 2021 by the authors. Licensee MDPI, Basel, Switzerland. This article is an open access article distributed under the terms and conditions of the Creative Commons Attribution (CC BY) license (https:// creativecommons.org/licenses/by/ $4.0 /)$.

\begin{abstract}
Analysis of long-term rainfall trends provides a wealth of information on effective crop planning and water resource management, and a better understanding of climate variability over time. This study reveals the spatial variability of rainfall trends in Sri Lanka from 1989 to 2019 as an indication of climate change. The exclusivity of the study is the use of rainfall data that provide spatial variability instead of the traditional location-based approach. Henceforth, daily rainfall data available at Climate Hazards Group InfraRed Precipitation corrected with stations (CHIRPS) data were used for this study. The geographic information system (GIS) is used to perform spatial data analysis on both vector and raster data. Sen's slope estimator and the Mann-Kendall (M-K) test are used to investigate the trends in annual and seasonal rainfall throughout all districts and climatic zones of Sri Lanka. The most important thing reflected in this study is that there has been a significant increase in annual rainfall from 1989 to 2019 in all climatic zones (wet, dry, intermediate, and Semi-arid) of Sri Lanka. The maximum increase is recorded in the wet zone and the minimum increase is in the semi-arid zone. There could be an increased risk of floods in the southern and western provinces in the future, whereas areas in the eastern and southeastern districts may face severe droughts during the northeastern monsoon. It is advisable to introduce effective drought and flood management and preparedness measures to reduce the respective hazard risk levels.
\end{abstract}

Keywords: CHIRPS data; climate change; climate hazards; climate zone; natural hazards; MannKendall test; rainfall; rainfall trend; Sen's slope estimator; Sri Lanka

\section{Introduction}

The global climate system has undergone unprecedented changes due to global warming since the 1950s, and continuous climate change will affect many countries, increasing the risk of flood and drought and other natural disasters, which will finally adversely affect the agricultural economy [1-4]. Climate change studies have become an essential part of understanding and predicting climate change as it exacerbates the effects of natural disasters such as floods, droughts, heavy rainfall, and temperature [5].

Numerous studies conducted in the recent past have shown that there is a growing rainfall variability globally, regionally, and sub-regionally [6-11]. North and Central Asia, the eastern regions of North and South America, and northern Europe are particularly prone to increased rainfall [12-14], while Northern and Southern Africa, the Mediterranean, and some other regions receive less rainfall. Although a significant increase in rainfall has been observed in Brazil's northern Amazon region, it has been shown to show a tendency to decrease rainfall as it extends to the southern regions [15]. Considering the context of India, it seems that for different states, the rainfall trend can be identified as both positive and negative [15-19]. In addition, some studies have shown that urban temperature is rising in Sri Lanka [20]. Analysis of rainfall trends has become a research field that has attracted great interest and enthusiasm in recent times [21]. However, as the global or regional scale declines to the national or sub-national level, further localized variations can 
be observed [22]. Moreover, rainfall analysis provides essential information for decisionmakers on activities such as water resource management, development, policy planning, and disaster preparedness [23]. The same scenario also reported that there has been a significant change in rainfall trend in Sri Lanka over the last few decades [24]. Due to the geographical context of Sri Lanka, the Indian Ocean (IO) monsoon system influences the systematic migration of rainfall over the country's various geographical areas throughout the year [25].

El Niño and La Niña significantly affect the Indian Ocean monsoon system, changing the country's rainfall and temperature. In the event of El Niño, Walker circulation weakens as the eastern Pacific warms abnormally, and sinks in the western Pacific, extending into the mid-Indian Ocean region during the summer [26-32]. Thus, in general, the rainfall in Sri Lanka decreases from July to August and from January to March, while the northeastern monsoon receives more rainfall during the period from October to December due to the movement of the Indian Ocean Walker cell to the east [32].

On the other hand, in Sri Lanka, like many other South and Southeast Asian countries, paddy is grown as a major crop all over the country $[33,34]$. Compared to the last few decades, the area used for paddy cultivation and production in Sri Lanka has increased steadily and this has been influenced by various socio-economic, political, cultural, and technological methods [35]. However, there are two main crop seasons in Sri Lanka, called Yala and Maha, and crop failures in the dry zone have been reported for many years (2001, 2004, 2016-2018) due to unprecedented floods and droughts [36,37]. Early or late onset of rainfall should determine the strategies to be adopted for the commencement of cultivation. In addition, rainfall is the primary source of water for each field, and its quantitative value determines whether an area is normal or whether there will be a drought or flood in that area. Therefore, the study of rainfall trends helps to identify the prevalence of floods and drought in a particular area [5].

As an example, a large number of studies on rainfall trends in Sri Lanka have been conducted over the past three decades and identified different localized variabilities in the country [21,38-42]. A recent study [21] showed that the eastern, southeastern, northern, and north-central parts of Sri Lanka have been experiencing an increase in rainfall over the past 31 years (1987-2017), and that there has been a decrease in the trend of rainfall in the western, northwestern, and central parts of the country.

Although many studies have been conducted to understand the rainfall trends in Sri Lanka, most of those studies focused only on data gathered from a limited number of rainfall stations $[21,24,43]$. Therefore, spatial variability was not captured in those studies. Such studies' main disadvantage is that they are not appropriate to represent trends at the district or climatic zone level, as the calculated values are limited to a small area. As reported in previous studies, the best way to avoid the above limitations is to use satellite precipitation estimates that, calibrated with stations data, accurately represent the spatial variability of rainfall events [44-47].

In recent times, satellite-based and reanalyzed rainfall observations (raster data) have become a better solution to gauge precipitation data with greater accuracy and higher spatial and temporal resolution [48]. Tropical Rainfall Measuring Mission (TRMM), Global Precipitation Climatology Center (GPCC), Asian Precipitation-Highly-Resolved Observational Data Integration Towards Evaluation (APHRODITE), Global Precipitation Measurement (GPM), Precipitation Estimation from Remotely Sensed Information using Artificial Neural Networks (PERSIANN) and Climate Hazards Group InfraRed Precipitation with Stations data (CHIRPS) are some of the well-known major rainfall products. Furthermore, out of the above rainfall estimates, CHIRPS data have been widely used for rainfall tendency analysis, and many of those studies emphasized the suitability of CHIRPS [49] data for identifying precipitation trends. Henceforth, daily rainfall data available at Climate Hazards Group InfraRed Precipitation corrected with Stations data (CHIRPS) have been used for this study. Conversely, because CHRPS data are a global product, it is important to understand the validity of data using local rainfall measurements when using it for a 
specific area. In this study, the determination of the validity of CHRPS data as a primary requirement is also introduced.

The study used statistical methods such as the Mann-Kendall (M-K) test and Sen's slope estimator to analyze the rainfall trend at the district and climatic zone level in Sri Lanka [8-14]. Even though the validity of CHIRPS precipitation data has already been established by many researchers in the global context, which is also applied for the countries in the tropics [49-51], an additional cross validation process was perforemed using location-specific rainfall data through the linear regression method.

\section{Materials and Methods}

\subsection{Study Area}

Sri Lanka is an island (Figure 1) which is located below the Indian subcontinent between latitudes $5^{\circ}$ and $10^{\circ} \mathrm{N}$ and longitudes $79^{\circ}$ and $82^{\circ} \mathrm{E}$. According to the Department of Census and Statistics, by 2020, Sri Lanka's total population increased to slightly over 21 million, and the total land area is about 65,000 square kilometers [52]. Furthermore, the main administrative units of Sri Lanka comprise nine provinces, 25 districts, and 331 divisional secretariat divisions (DSD). The coastline, coastal plains, inland plains, southcentral mountain ranges, and isolated mountain ranges are the main topographical features of the island. The altitude ranges from 0 to $2505 \mathrm{~m}$, and the highest peak is Piduruthagala. There are 103 rivers in Sri Lanka, covering 103 major and minor river basins.

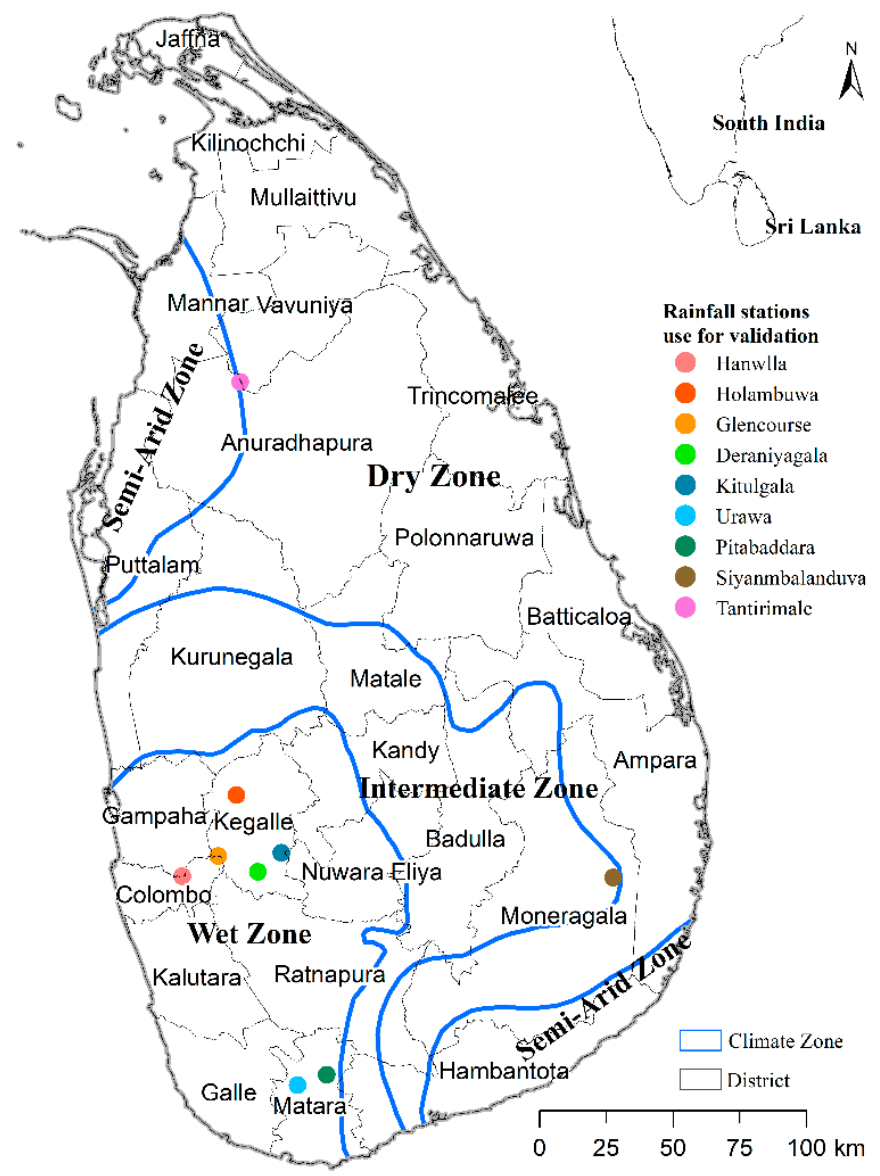

Figure 1. Districts, climatic zones, and rainfall stations (used only for cross validation) of Sri Lanka.

There are four major climatic zones in Sri Lanka: the "wet zone", "intermediate zone", "dry zone" and "semi-arid zone". The country's "wet zone", the western face of the mountain range, and the southwest windy slopes receive an average of $2500 \mathrm{~mm}$ of rainfall each year. The "dry zone" of Sri Lanka receives between 1200 and $1900 \mathrm{~mm}$ of 
rainfall, mainly through the northeast monsoon, and the semi-arid zone (northwestern and southeastern coasts) receives the lowest rainfall, which is between 800 and $1200 \mathrm{~mm}$.

The monsoon winds in the Indian Ocean and the depression and cyclones in the Bay of Bengal primarily affect the increase or decrease in rainfall in Sri Lanka [53]. Various studies have introduced four rainy seasons based on rainfall variations in Sri Lanka over a few decades $[54,55]$. Depending on the months of rain received, the rainy seasons are the first inter-monsoon (FIM) from March to April and the second inter-monsoon (SIM) is from October to November, while December to February constitute the northeastern monsoon (NEM), and the southwestern monsoon (SWM) occurs from May to September.

\subsection{Data}

CHIRPS data were used primarily for this study and are available daily. The daily data were then downloaded from the Climate Hazard Center and these data are available as daily-grided rainfall from 1989 to 2019 for this study [48]. In generating CHIRPS data, precipitation data estimated by satellites with a spatial resolution of $5 \mathrm{~km}$ were integrated with location-based rainfall.

Location-specific rainfall data (daily rainfall data) from nine (09) gauge points as a ground-measured source were downloaded from the https://www.irrigation.gov.lk/ (accessed on 31 December 2020) website and converted into monthly accumulation. Data from these nine rainfall stations out of 33 total stations and three years of data (2015 to 2017) were used for the aforementioned cross validation process. The precipitation gauge points used for the analysis were Hanwlla, Glencourse, Deraniyagala, Kitulgala, Holambuwa (Kelani river basin), Pitabaddara, Urawa (Nilwala river basin), Siyanmbalanduva (Heda Oya river), and Tantirimale (Malwatu Oya river), respectively (Figure 1). The nine rainfall stations mentioned above are those with the highest accuracy, as the rest of the stations have significant data gaps for the considered three-year period. Moreover, it is important to state that these station data, freely available at the Irrigation Department of Sri Lanka, have been available since 2015. On the other hand, Sri Lanka received heavy rainfall as well as severe droughts during the period between 2015 and 2017 [56-58]. Therefore, this three-year data analysis represents the validity that CHIRPS data shows during drought as well as heavy rainfall. It is important to mention that through the cross-validation process, we attempt to further emphasize the relevance of CHIRPS data in the Sri Lankan context.

\subsection{Methodology}

Daily rainfall data downloaded from the aforementioned nine rainfall stations were used for the cross-validation process as an additional task which did not affect the findings of this study. Since those station-based rainfall data are available at a daily level, the monthly rainfall was calculated using the daily accumulation of a month. Then, the linear regression was used to observe the correlation between the monthly CHIRPS and the station data.

The downloaded CHIRPS data were in the NetCDF (Network Common Data Format) file format. R-Studio software was used to process these data, as an annual stack of 365 layers. Seasonal and annual rainfall data were generated using CHIRPS daily rainfall accumulation. Since these rainfall data are in raster format, the geo-spatial data analysis method such as cell statistics was used to complete the above process. Subsequently, the seasonal and annual average rainfall values for each year (1989 to 2019) for each district and climate zone used in this study were calculated with the zonal statistics method of spatial statistics. Therefore, the geographical information system (GIS) played a vital role during the spatial data processing. Then, the rainfall trends were analyzed separately at district and climatic zone level. Moreover, the precipitation trend direction (increasing-positive or decreasing-negative) and its magnitude were also calculated at the district and climate zone level using Mann-Kendall's test and Sen's slope estimator, respectively. 


\subsubsection{Mann-Kendall Test}

The Mann-Kendall probability test can be abbreviated as the M-K test. The leastsquare linear regression method is more commonly used than other statistical methods to determine long-term trends for seasonal, annual, and daily maximum rainfall [59]. However, since it is a parametric test, it usually requires a normally distributed timeseries dataset to conduct the test. Among the various time-series trend detection tests, the $\mathrm{M}-\mathrm{K}$ test is most commonly used to determine the trends of rainfall, temperature, river discharge, etc. However, the $\mathrm{M}-\mathrm{K}$ test [60] is a non-parametric test, which means that it works for all types of distributions and it indicates whether the direction of inclination of the given parameter is positive or negative, but the magnitude of the inclination is often estimated using Sen's Slope estimate [61]. Mann-Kendall's statistics " $S$ " can be calculated by Equations (1) and (2).

$$
\begin{gathered}
S=\sum_{i=1}^{n-1} \sum_{j=i+1}^{n} \operatorname{sgn}\left(x_{j}-x_{i}\right) \\
\operatorname{sgn}\left(x_{j}-x_{i}\right)=\left\{\begin{array}{c}
+1,>\left(x_{j}-x_{i}\right), \\
0,=\left(x_{j}-x_{i}\right), \\
-1,<\left(x_{j}-x_{i}\right)
\end{array}\right\}
\end{gathered}
$$

where $x_{j}$ and $x_{i}$ are sequential data values and $n$ is the number of time-series data. The positive and negative values of $S$ represent a "high tendency" and "low inclination", respectively.

If the number of records used for the test is greater than $10(N>10)$, then the average distribution statistic is approximately equal to zero and the variance of $S$ is calculated using Equation (3). Usually, more than ten records are used to analyze the trend of the time series.

$$
\operatorname{Var}(s)=\frac{n(n-1)(2 n+5)-\sum_{i=1}^{m} t_{i}(i)(i-1)(2 i+5)}{18}
$$

where $t_{i}$ is the number of bonds specified in sample $i$. Then, Mann-Kendall's statistics Zc (standard average deviation) for $N>10$ is calculated using Equation (4).

$$
Z c=\left\{\begin{array}{l}
\frac{S-1}{\sqrt{\operatorname{Var}(S)}}, \quad S>0, \\
0, \quad S=0, \\
\frac{S+1}{\sqrt{\operatorname{Var}(S)}}, \quad S<0 .
\end{array}\right\}
$$

$Z c$ follows the standard normal distribution. A positive $Z c$ value shows an increasing trend, while the negative $Z c$ data give a decreasing trend for the period. If $Z c \mid>z \alpha / 2$, the null hypothesis is rejected.

\subsubsection{Sen's Slope Estimation}

The magnitude of the direction generated by the $\mathrm{M}-\mathrm{K}$ test can be calculated using Sen's slope estimator. Sen's slope estimator does not calculate the general straight and linear trend value of the time series data, where the true slope which changes in time is estimated using a procedure developed by Sen (1968). The test is widely used to estimate the magnitude of the trend in rainfall ranges over time. Slope pairs can be calculated for all data using Equation (5);

$$
T_{i}=\frac{x_{j}-x_{k}}{j-k} \text { for } i=1,2,3, \ldots \ldots n, j>k,
$$

where $T_{i}$ is the slope and $x_{j}$ and $x_{k}$ are the data values at time $j$ and $k$, respectively. 
The mean of the $n$ values of $T_{i}$ is encoded as Sen's slope estimator $\left(Q_{i}\right)$ and is calculated using Equation (6);

$$
Q i=\left\{\begin{array}{ll}
\left(T_{(n+1 / 2)}\right), & n \text { is } 0 d d, \\
\frac{1}{2}\left(T_{(n / 2)}+T_{(n+2) / 2}\right), & n \text { is even }
\end{array}\right\}
$$

\section{Results}

As described in the sections above, a cross validation process was performed on CHIRPS data as an additional task. The CHIRPS data were analyzed according to the steps stated above and mapped the spatial distribution of rainfall trends at the district and climatic zone levels. This is beyond just presenting general statistical parameters.

\subsection{Cross Validation of CHIRPS Data}

Although nine rainfall locations were used to determine the correlation of rainfall, the monthly rainfall variations from 2015 to 2017 for the Hanwella, Pitabadra, Siyambalanduwa, and Tantirimale rainfall stations are shown in Figure 2. Hanwella and Pitabadra are located in the wet zone and Siyambalanduwa and Tantirimale can be observed in the north and south of the dry zone, respectively. In 2015, the SWM was average, and in 2016 as well as in 2017, it was clear that there was an increase in wetness. Nevertheless, the other two years in the dry zone apart from 2015 were marked as dry. The other important thing is that the second monsoon rains are better during these three years for wet zone locations compared to the dry zone.

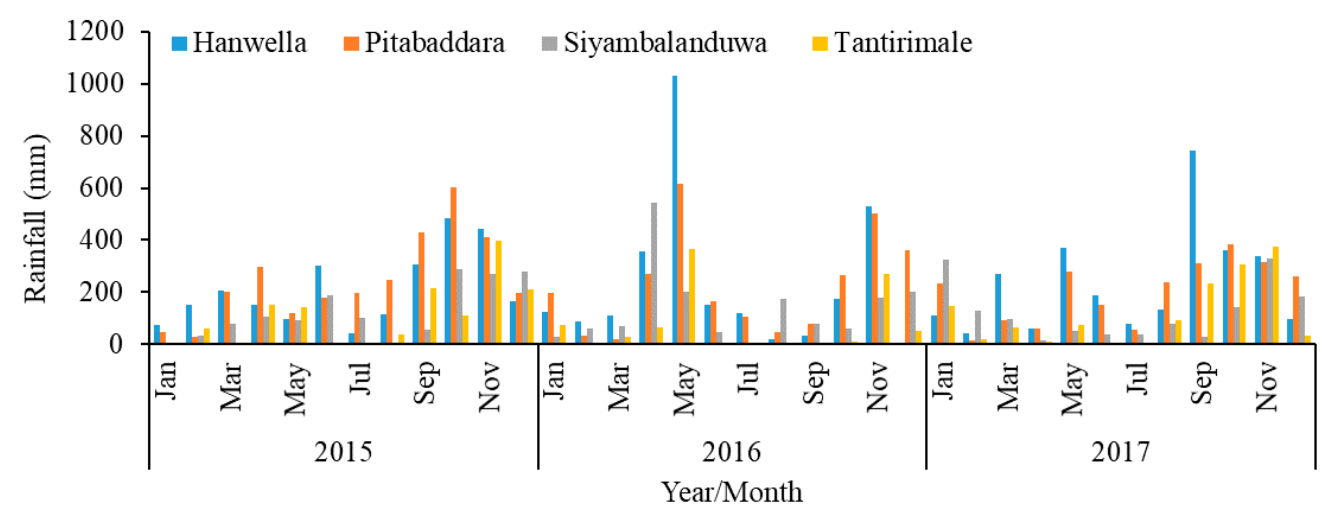

Figure 2. Monthly rainfall changes in four stations from 2015 to 2017 (used only for cross validation).

Since CHIPRS data are used entirely for this study, performing a cross validation process to observe the correlations with location-based data would give an initial positive impression on the study. For this purpose, scatter-plot charts were used to determine the correlation between ground-measured rainfall data and CHIRPS data, as shown in Figure 3, and the Pearson correlation coefficient was used to determine the magnitude of the correlation. Instead of performing this for the entire study period, only three years, 2015, 2016, and 2017, were used, which cover all climatic extremes, such as droughts, unusual rainfall, and severe floods, during that particular year range.

For rainfall locations which were selected for cross validation, the corresponding CHIRPS pixel's precipitation values were extracted to determine the accuracy between them. The maximum correlation on the coefficient is represented by Figure $3 \mathrm{~b}$ and is approximately 0.91, Station-based rainfall measurements and CHIRPS data show an excellent correlation; therefore, cross validation performed on CHIRPS data provides a positive impression for the study. 

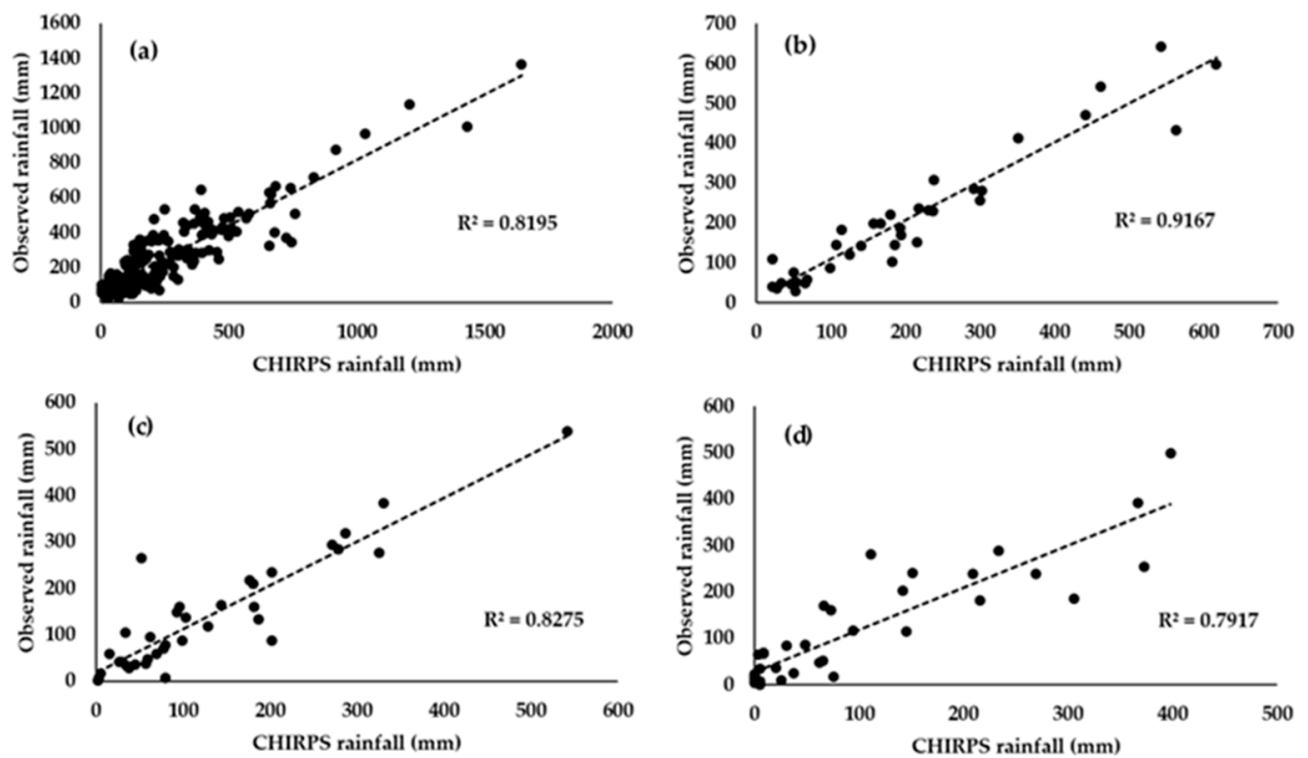

Figure 3. Scatter plot between Climate Hazards Group InfraRed Precipitation with Stations data (CHIRPS) rainfall products and ground-based rainfall measurements from the year 2015 to 2017, and linear compatibility is also shown with $\mathrm{r}^{2}$. (a) five rainfall stations in the western province; (b) two rainfall stations in the southern province; (c) one station in the eastern province; (d) one station in the north-central province.

\subsection{Descriptive Statistics Generated Using CHIRPS Data}

Figure 4 shows the changes in the annual rainfall of Sri Lanka, as well as wet, dry, intermediate, and semi-arid zones from 1989 to 2019. Furthermore, the spatial and temporal variability of rainfall can be identified, all of which usually show a variety of variance patterns, but overall, there is a tendency for rainfall to increase. Considering only the average annual rainfall of Sri Lanka, it can be seen that the maximum rainfall was received in 2010, 2011, and 2014. During these three years, the country experienced major floods [58]. The 2010 and 2014 floods occurred in the wet zone, and in 2011 in the dry zone. Despite the heavy rains that accompanied the catastrophic floods of 2016 and 2017 in the wet zone, Sri Lanka's overall rainfall declined during those two years. The main reason for this is the decline in rainfall in the dry zone during the period of 2016-2018.

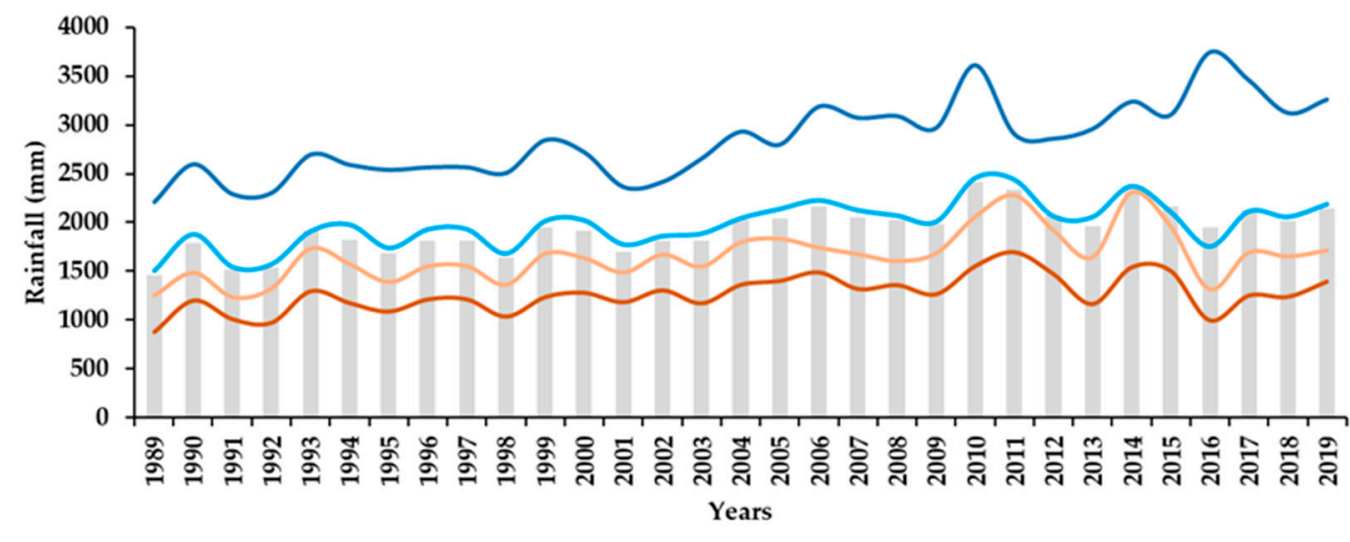

Sri Lanka —Wet-zone - Dry-zone - Intermediate-zone - Semi-Arid-zone

Figure 4. Annual average rainfall distribution in wet, dry, intermediate, semi-arid zones, and Sri Lanka from 1989 to 2019.

The other notable feature is the decrease in the total rainfall in Sri Lanka from 2015 to 2019. However, in 2016 and 2017, the wet zone received the highest recorded rainfall in its 
30-year history. In contrast to the wet zone, the dry zone showed relatively low rainfall from 2015 to 2019, resulting in drought/dry conditions during the "Maha" season in 2016 to 2018. Therefore, the rainfall variation is very close to the terrestrial reality when viewed at the country or region level, as shown in Figure 4. On the other hand, this is one of the excellent examples to show the accuracy of CHIRPS data.

Table 1 shows the descriptive statistical parameters called mean, maximum, minimum, standard deviation, median, and coefficient of variance of the annual rainfall at the district level. The highest average annual rainfall between 1989 and 2019 was recorded in Kalutara district $(3340.2 \mathrm{~mm})$, and the lowest was recorded in Kilinochchi district $(1109.7 \mathrm{~mm})$. The observed specialty of the analysis of the maximum and minimum rainfall time series is that the maximum average rainfall value of $4489.4 \mathrm{~mm}$ was recorded in the year 2019 in the Kalutara district. Further study shows that the lowest maximum, $1619.8 \mathrm{~mm}$ in the Jaffna district, was observed in 1993, which is almost three times lower than the peak recorded in the Kalutara district in 2019.

Table 1. Descriptive statistics for annual rainfall (in mm) at district wise generated using CHIRPS data from 1989 to 2019.

\begin{tabular}{|c|c|c|c|c|c|c|c|c|}
\hline District & Average & Max & Min & STD & $\mathrm{CV}$ & Median & 1st Quartile & 3rd Quartile \\
\hline Colombo & 2993.5 & 3982.5 & 2329.6 & 404.5 & 13.5 & 2968.3 & 2632.1 & 3184.5 \\
\hline Galle & 2997.6 & 4319.0 & 2257.1 & 468.2 & 15.6 & 2940.0 & 2623.2 & 3285.5 \\
\hline Gampaha & 2554.2 & 3483.0 & 2094.6 & 351.9 & 13.8 & 2581.6 & 2211.3 & 2791.8 \\
\hline Kalutara & 3340.2 & 4489.4 & 2628.5 & 480.7 & 14.4 & 3275.5 & 2995.0 & 3672.8 \\
\hline Kandy & 2389.6 & 2984.4 & 1680.0 & 297.9 & 12.5 & 2420.5 & 2229.7 & 2603.3 \\
\hline Kegalle & 2942.1 & 3919.7 & 2332.8 & 373.1 & 12.7 & 2909.1 & 2662.9 & 3199.6 \\
\hline Matara & 2589.8 & 3667.0 & 1756.4 & 398.0 & 15.4 & 2513.3 & 2302.8 & 2824.3 \\
\hline Nuwara Eliya & 2509.3 & 3135.8 & 1713.1 & 304.4 & 12.1 & 2548.6 & 2373.3 & 2691.0 \\
\hline Ratnapura & 2759.7 & 3531.3 & 2076.8 & 343.5 & 12.4 & 2743.0 & 2556.7 & 2970.9 \\
\hline Badulla & 2082.1 & 2716.2 & 1364.0 & 280.9 & 13.5 & 2119.0 & 1974.2 & 2224.1 \\
\hline Kurunegala & 1762.0 & 2345.1 & 1354.6 & 251.8 & 14.3 & 1734.6 & 1626.4 & 1945.8 \\
\hline Matale & 2063.7 & 2768.3 & 1494.9 & 308.3 & 14.9 & 2074.2 & 1933.3 & 2188.8 \\
\hline Ampara & 1697.9 & 2597.3 & 1000.2 & 307.1 & 18.1 & 1709.6 & 1620.4 & 1838.9 \\
\hline Anuradhapura & 1469.7 & 2161.0 & 1066.5 & 267.5 & 18.2 & 1421.8 & 1323.6 & 1602.7 \\
\hline Batticaloa & 1540.3 & 2485.4 & 911.8 & 311.9 & 20.2 & 1547.3 & 1371.7 & 1708.8 \\
\hline Jaffna & 1118.4 & 1690.0 & 614.6 & 282.4 & 25.3 & 1087.0 & 984.1 & 1310.4 \\
\hline Kilinochchi & 1109.7 & 1695.3 & 565.7 & 287.7 & 25.9 & 1114.5 & 911.2 & 1287.0 \\
\hline Moneragala & 1698.4 & 2267.8 & 1043.4 & 244.1 & 14.4 & 1755.4 & 1619.2 & 1819.0 \\
\hline Mullaitivu & 1357.4 & 2081.3 & 809.3 & 317.9 & 23.4 & 1351.0 & 1156.5 & 1537.6 \\
\hline Polonnaruwa & 1795.2 & 2689.1 & 1223.8 & 312.0 & 17.4 & 1750.7 & 1626.6 & 1863.1 \\
\hline Trincomalee & 1511.8 & 2468.3 & 893.0 & 312.0 & 20.6 & 1433.7 & 1295.2 & 1707.9 \\
\hline Vavuniya & 1475.4 & 2210.2 & 994.5 & 289.2 & 19.6 & 1448.3 & 1295.3 & 1637.0 \\
\hline Hambantota & 1393.4 & 1774.7 & 841.6 & 201.2 & 14.4 & 1398.2 & 1280.6 & 1510.4 \\
\hline Puttalam & 1358.6 & 1847.0 & 1049.0 & 220.8 & 16.3 & 1329.6 & 1199.1 & 1516.1 \\
\hline Mannar & 1258.0 & 1821.4 & 776.6 & 262.1 & 20.8 & 1257.6 & 1076.2 & 1434.2 \\
\hline
\end{tabular}

Considering the four climatic zones of Sri Lanka, the highest annual average rainfall in the wet zone is $2876.7 \mathrm{~mm}$, followed by the intermediate zone $(1979.3 \mathrm{~mm})$, the dry zone (1520.6), and the semi-arid zone $(1264.6 \mathrm{~mm})$, and it is represented by Table 2. Another notable feature of this is that the average annual rainfall variability is higher in the wet zone than in the dry zone. The coefficient of variance $(\mathrm{CV})$ is generally used to understand the inter-annual variability and variability level of rainfall. The CV value varies from 12.1 to 25.9 in all districts of Sri Lanka, with a maximum in Kilinochchi and a minimum in Nuwara Eliya. 
Table 2. Descriptive statistics for annual rainfall (in $\mathrm{mm}$ ) at climatic zones wise generated using CHIRPS data from 1989 to 2019 .

\begin{tabular}{ccccccccc}
\hline Climate Zone & Average & Max & Min & STD & CV & Median & 1st Quartile & 3rd Quartile \\
\hline Dry & 1520.6 & 2255.8 & 990.8 & 252.7 & 601.8 & 1492.5 & 1421.8 & 1632.5 \\
Wet & 2876.7 & 3719.1 & 2280.4 & 354.8 & 810.7 & 2863.0 & 2625.4 & 3100.7 \\
Intermediate & 1979.3 & 2454.1 & 1502.3 & 236.6 & 836.5 & 2012.7 & 1866.3 & 2108.7 \\
Semi-Arid & 1264.6 & 1697.4 & 873.2 & 189.0 & 669.2 & 1249.2 & 1170.2 & 1377.2 \\
\hline
\end{tabular}

According to the [37] classification of CV, 6 out of 25 districts fall into the high variability class and the rest into the middle class. The peculiarity here is that all districts in the wet and intermediate zones belong to the middle CV class only, with about $50 \%$ of the districts in the dry and semi-arid zones showing high variability. The districts with the highest rainfall variability are Mannar, Trincomalee, Mullaitivu, Kilinochchi, Jaffna, and Batticaloa. Since rainfed agriculture is common in most of these districts, it can have a significant impact due to high rainfall variability.

Sen's slope and Kendall's tau values were calculated at a 0.05 significance level using the M-K trend test for the annual rainfall (1987-2019) covering 25 districts in Sri Lanka. Figure 5 shows how the values of Sen's slope and Kendall's tau vary for each district. The two-tailed Mann-Kendall trend test used for this study is of 5\% significance (Kendall's tau) and has 95\% confidence in Sen's slope. The results of the M-K trend test on the annual rainfall show that there is a trend for an increase in rainfall in all districts and it is very clear that except for four districts, the other entire districts show a significant rainfall trend. The districts that do not show a significant trend are Ampara, Batticaloa, Jaffna, and Kilinochchi (Table A1).

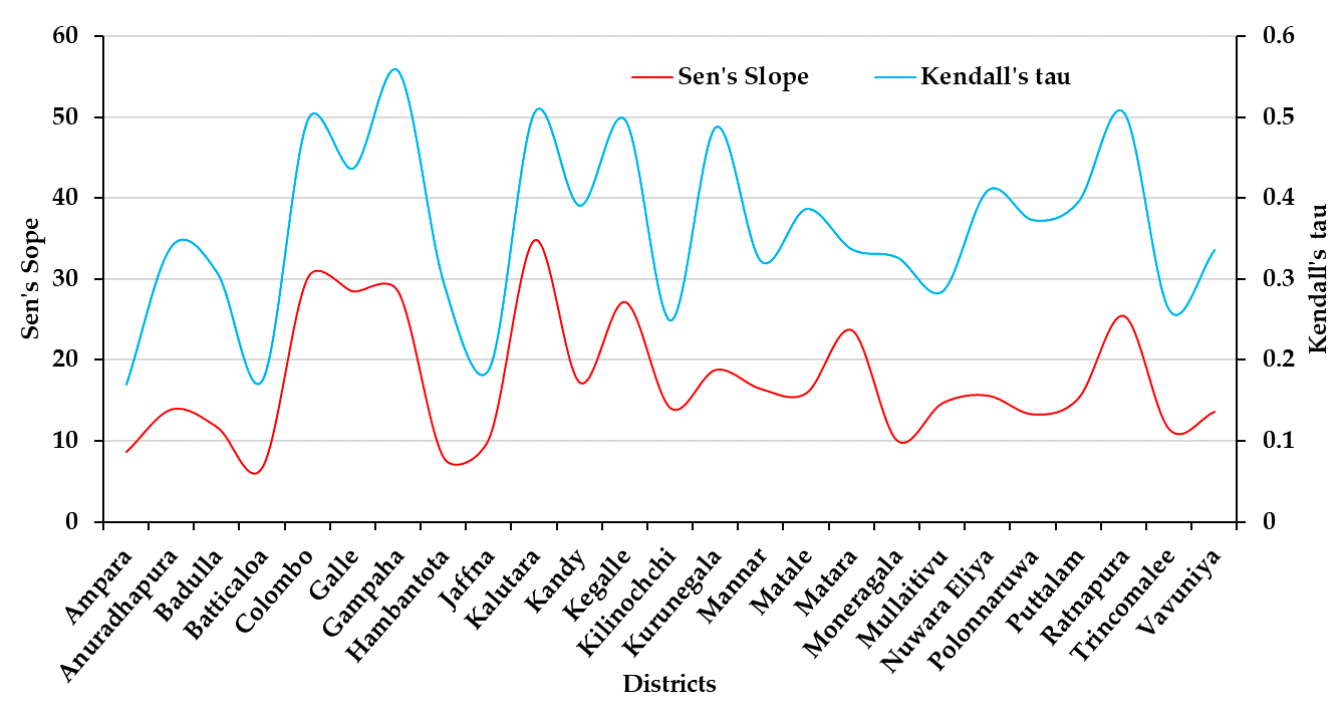

Figure 5. Distribution of Kendall's tau value and Sen's slope derived for each district for annual rainfall from 1989 to 2019.

The highest rainfall trend is seen in Kalutara district (34.84 mm/year), followed by Colombo (30.22 mm/year), Galle (28.51 mm/year), Gampaha ( $28.43 \mathrm{~mm} /$ year), Ratnapura $(25.48 \mathrm{~mm} /$ year), and Matara $(23.71 \mathrm{~mm} /$ year), while the lowest is in Batticaloa (6.74 mm/year), followed by Hambantota $(7.91 \mathrm{~mm} /$ year), Ampara $(8.64 \mathrm{~mm} /$ year), and Jaffna (10.33 mm/year). In general, with the spread of the districts (Figure 1), there is an increase in rainfall in both the wet and dry zones. Nevertheless, it is essential to study them separately to understand the precipitation trend in those climatic zones. 


\section{Discussion}

This section mainly discusses the trend of seasonal rainfall over the past 30 years in Sri Lanka. Analysis of the seasonal rainfall trend helps farmers to manage their cultivation practices better and plan the crops. Furthermore, these analyses are of great help in managing long-term hazards such as floods and drought. The climate of Sri Lanka can be divided into two monsoons and two inter-monsoon seasons, namely, the southwestern monsoon (SWM), the northeastern monsoon (NEM), and the first and second inter-monsoon (FIM, SIM), respectively.

The two-tailed Mann-Kendall trend test was also employed to identify seasonal rainfall trends with $5 \%$ significant and $95 \%$ confidence levels. The variation of the values determined by the M-K test for the four seasons of rainfall is graphically illustrated in Figure 6. For the Kalutara and Hambantota districts, the variation in annual, SWM, NEM, FIM, and SIM rainfall is illustrated in Figure 7, respectively, and the Sen's slope is shown together with the rainfall variation. This gives an obvious idea of the direction and magnitude of the rainfall trend.
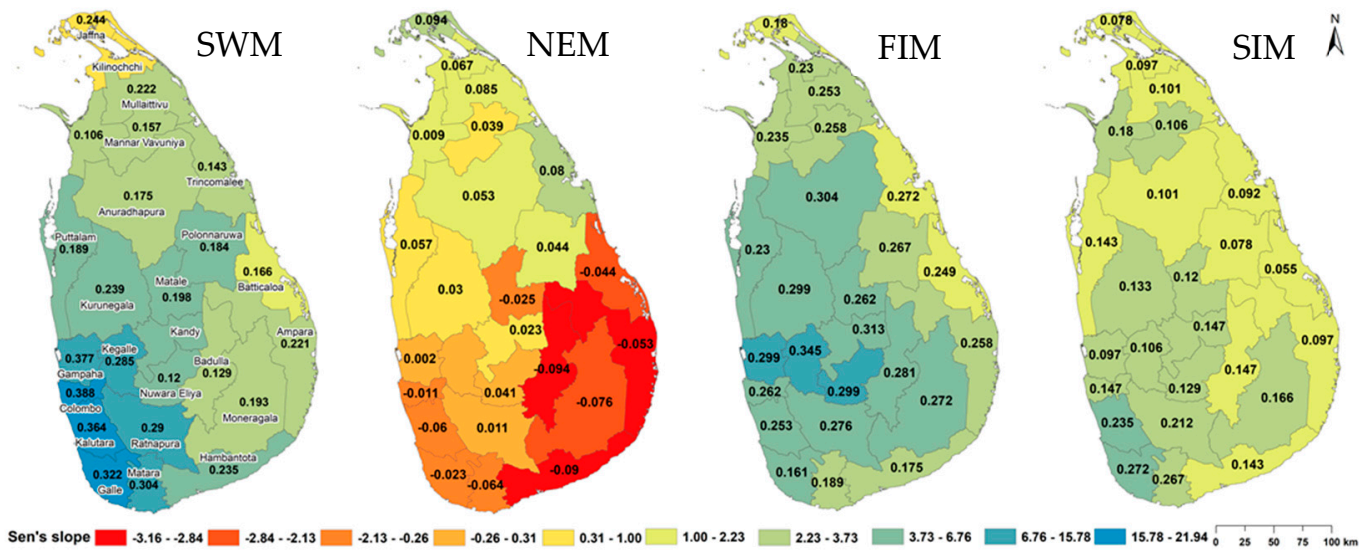

Figure 6. Representation district level Sen's slope (colour gradient) and Kendall's tau value (numbers) for different monsoon seasons of Sri Lanka.

However, the results of the $\mathrm{M}-\mathrm{K}$ trend test show that there is an increase in rainfall in all districts of Sri Lanka during the SWM, but only seven districts show a significant trend. All these districts fall in the country's wet zone, namely Colombo, Gampaha, Galle, Kalutara, Ratnapura, Matara, and Kegalle, respectively. Similar to the annual rainfall trend, the highest trend was recorded in SWM from Kalutara (21.943 mm/year) district and the lowest from Kilinochchi ( $0.978 \mathrm{~mm} /$ year) district (Table 3).

An important point that emerges from the analysis of M-K values in NEM is that no district shows a statistically significant trend in rainfall. The most important thing to note here is that about $40 \%$ of the districts represent a decreasing trend. The districts showing these negative values belong to all four climatic zones-wet, dry, intermediate, and semiarid—namely Ampara, Badulla, Batticaloa, Colombo, Galle, Hambantota, Kalutara, Matale, Matara, and Moneragala, respectively. The districts of Ampara, Moneragala, Batticaloa, and Badulla show a negative trend despite the fact that NEM is expected to receive more rainfall. Ultimately, this indicates that these districts are more prone to drought during the "Maha" season. Sri Lankan farmers had to experience this phenomenon in 2014, 2016, and 2017 [56]. 
Kalutara District
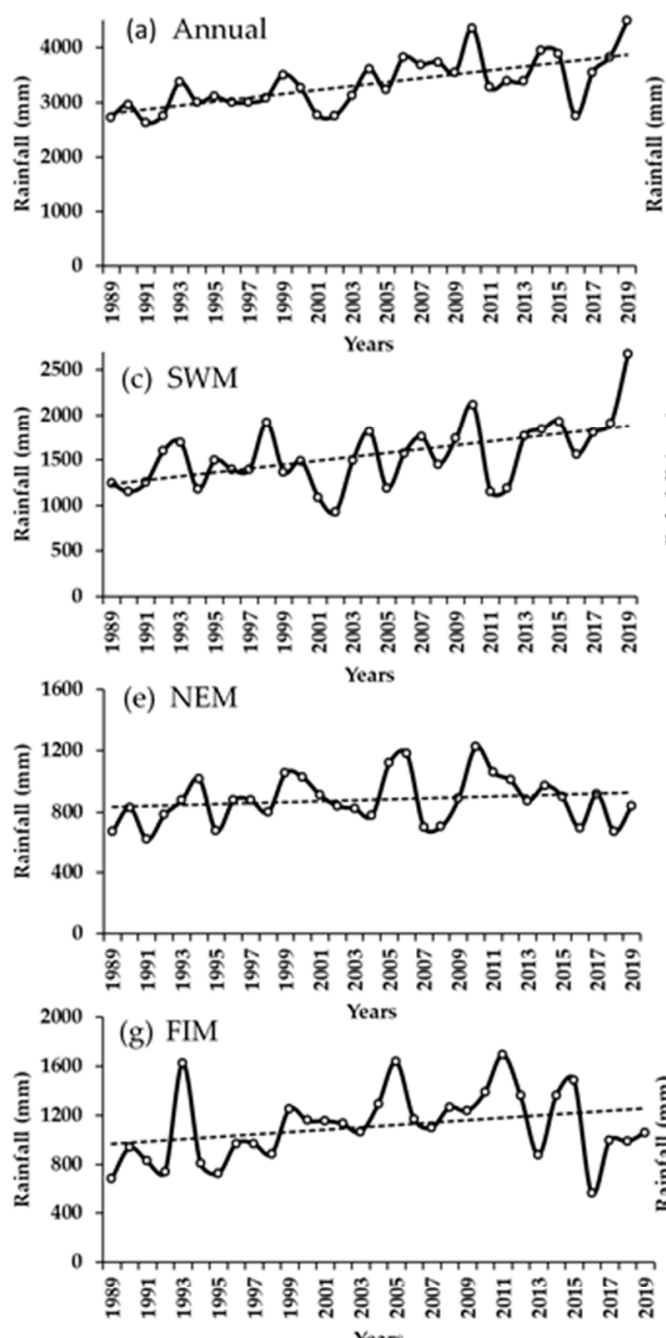

Hambantota District

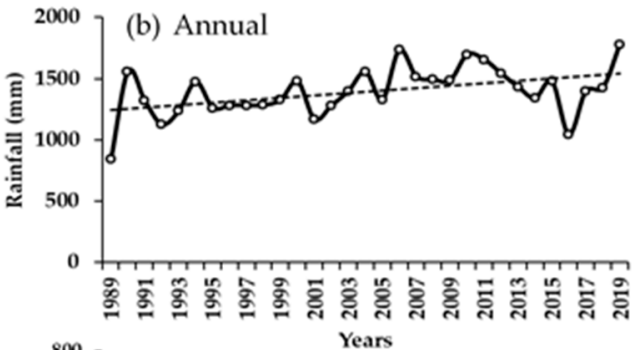

(d) SWM
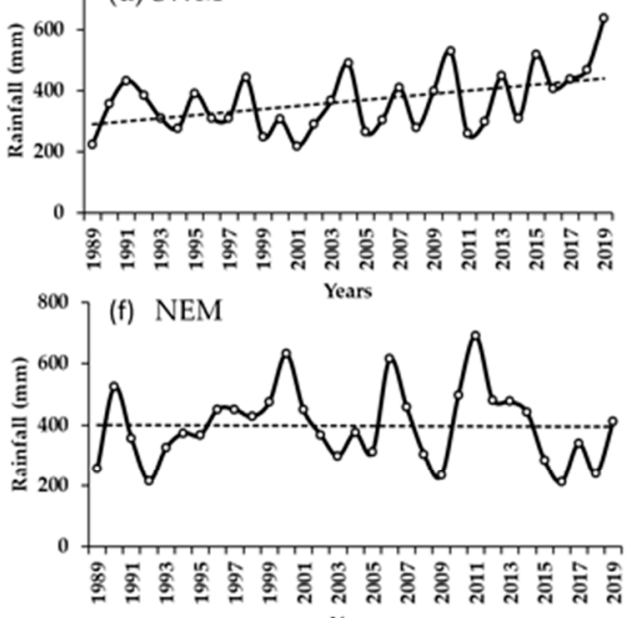

(h) FIM Years

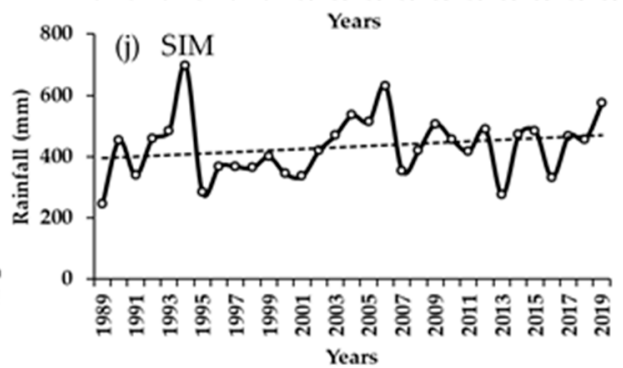

Figure 7. Rainfall trend of different temporal dimensions as annual, southwestern monsoon (SWM), northeastern monsoon (NEM), first inter-monsoon (FIM), and second inter-monsoon (SIM) in the Kalutara (a,c,e,g,i) and Hambantota districts $(\mathbf{b}, \mathbf{d}, \mathbf{f}, \mathbf{h}, \mathbf{j})$.

When further interpreting the results of the M-K test, as shown in Figure 6 and Table 3, there is an increased tendency for precipitation to increase for all districts during the FIM season. However, 17 districts (68\%) out of the total districts show a statistically significant increasing trend (at 0.05 significant level). The highest trend of rainfall of $9.39 \mathrm{~mm} /$ year is recorded in the Kegalle district and the lowest, $1.27 \mathrm{~mm} /$ year, is in the Jaffna district. Batticaloa, Galle, Hambantota, Jaffna, Kilinochchi, Mannar, and Matara are the seven districts which do not show a statistically significant rainfall trend. 
During the SIM, only Galle and Matara districts show a statistically significant rainfall trend of 6.28 and $6.09 \mathrm{~mm} /$ year, respectively. This shows that there has been no significant change in the intensity of rainfall in both the NEM and SIM seasons in the last 30 years.

Table 2 shows the statistical parameters such as average, maximum, minimum, standard deviation, mean, and variance coefficients of long-term (1989-2019) annual rainfall based on different climatic zones. Average precipitation values in the wet, dry, and intermediate zones are still well within their classification ranges, but the average value in the semi-arid zone is higher than the maximum in its range. Furthermore, analysis of the coefficient of variance demonstrates that greater inter-annual variability cannot be detected in any climate zone.

Figure 8 shows non-parametric M-K test results and the Sen's slope conducted with a 0.05 significance level for wet, dry, intermediate, and semi-arid climate zones of Sri Lanka. It is noteworthy that all of these climatic zones show a statistically significant trend. The highest trend $(31.301 \mathrm{~mm} /$ year $)$ is in the wet zone and the lowest $(11.549 \mathrm{~mm} /$ year $)$ is in the semi-arid zone. Increases in rainfall of $14.521 \mathrm{~mm} /$ year in the dry zone and $17.27 \mathrm{~mm} /$ year in the inter-zone are also shown (Table A2). From the above calculations, it can be concluded that there is a significant increase in rainfall from 1989 to 2019 in all climatic zones of Sri Lanka. Maps of annual rainfall trends of the district and climatic zones are shown in Figure 9.
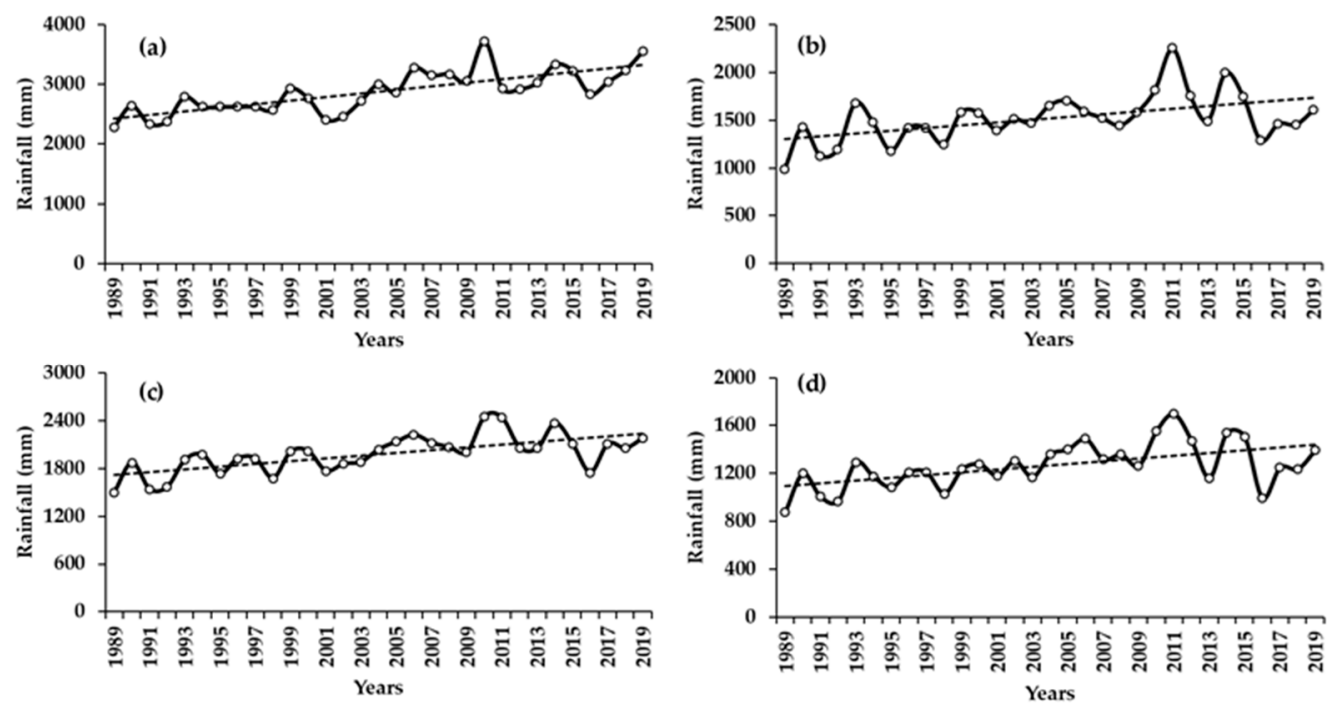

Figure 8. Rainfall trend for climate zones of Sri Lanka: (a) wet-zone; (b) dry-zone, (c) intermediate-zone, and (d) semiarid zone.

Although the districts of Jaffna and Kilinochchi were included in the dry zone, the annual average precipitation of the two was found to be less than the rainfall margin $(1250-1750 \mathrm{~mm})$ in the dry zone. These two districts seem to be moving out of the dry zone and into the semi-arid zone. Further study of the intermediate zone and its distribution in the districts shows that although the Kurunegala District represents about $70 \%$ of the intermediate zone's land area, the average annual rainfall of the district is less as 1762 $\mathrm{mm}$. A similar situation is observed in the Monaragala district as well (Table 1). That is, this value is best suited to represent the dry zone. However, in Badulla, Matale, and Kandy districts, the average rainfall is well within the intermediate-zone class margin. Considering all these factors, the main point to be concluded is that the margin separating the dry zone and the intermediate-zone has changed slightly. 


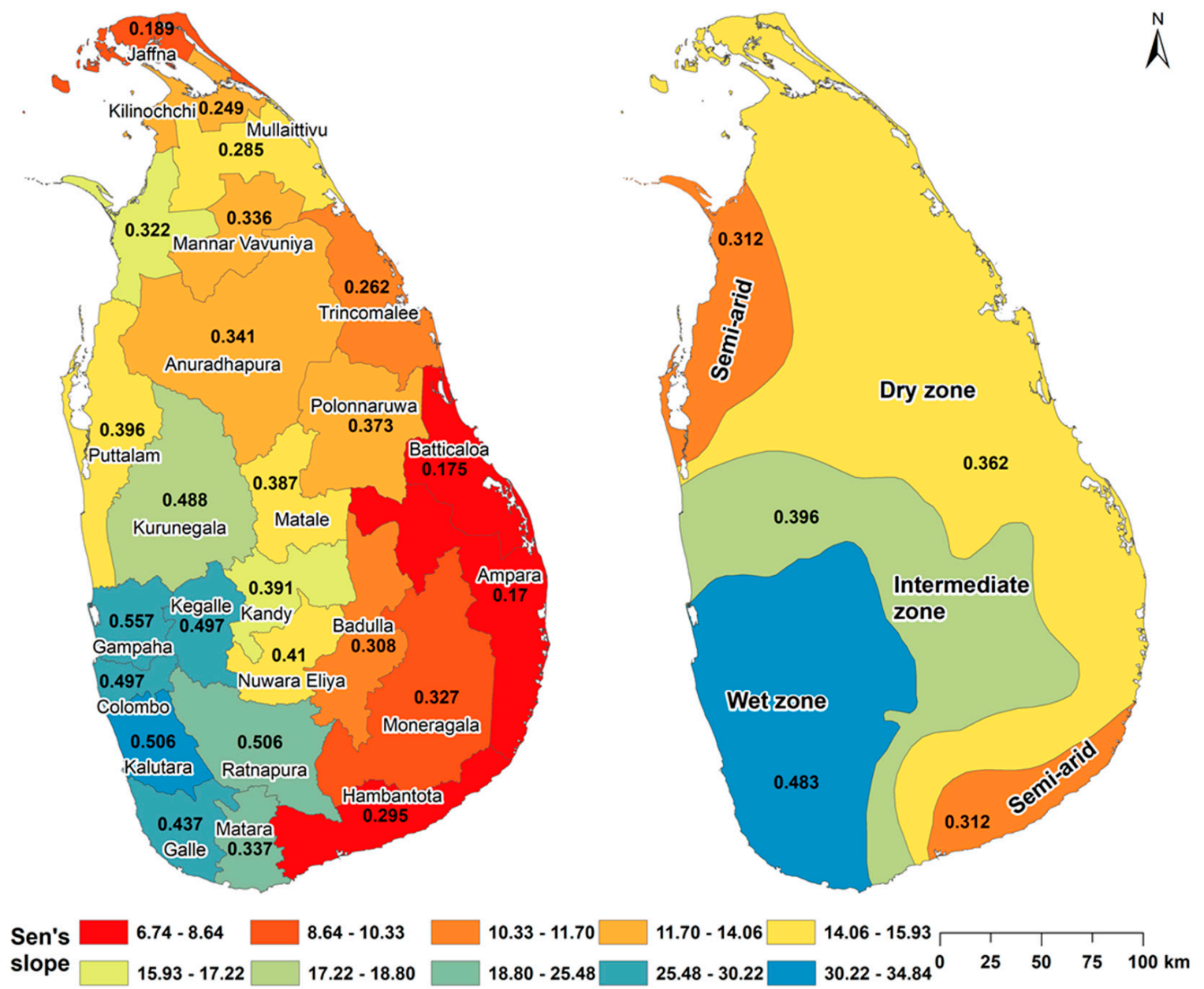

Figure 9. Representation of Sen's slope (colour gradient) and Kendall's tau (number) on changes in annual rainfall at district and climatic zone level.

This study suggests that the methodology followed in this study could be adopted for developing countries in tropical and subtropical regions that suffer from a lack of local rainfall measurements to analyze rainfall variability over time. Moreover, rainfall station data do not show a good spatial variability of rainfall in terms of the distribution of rainfall stations. This study emphasizes that monthly CHIRPS data can be used as a suitable replacement for station rainfall for precipitation trend analysis to represent the effect of climate variability in Sri Lanka. The findings of this study have the potential to be used as an indication of climate change in Sri Lanka and to provide guidance for decision-makers on disaster risk management and mitigation processes.

\section{Conclusions}

For the past 31 years, from 1989 to 2019, each district's rainfall trends covering 25 districts of Sri Lanka have been studied using the M-K test and Sen's slope estimator. The results of the M-K non-parametric statistics test show an increase in annual rainfall for every district in the country. However, the annual rainfall in all districts except four in the dry zone increased significantly during the study period, and Jaffna, Batticaloa, Kilinochchi, and Ampara can be identified as the districts which did not show such an increase. Seasonal precipitation analysis shows that only the wet zone districts show a significant increase in SWM rainfall. However, $40 \%$ of the districts in the NEM show a negative trend and the other $60 \%$ show a positive trend, but no statistically significant trend in any district. Districts showing negative trends are spread over all climatological zones in Sri Lanka. Considering the trends in rainfall over the past 31 years in the climatic zones of Sri Lanka, 
it can be concluded that there is a significant tendency for precipitation to increase in all climatic zones (wet, dry, intermediate, and semi-arid) of Sri Lanka. Here, the maximum increase is recorded in the wet zone and the minimum increase is recorded in the semi-arid zone. A good example to prove this is the impact on the salt pans in the Hambantota district. That is to say, the salt production decreases as the district receives rainfall throughout the year. Further confirming these trends, it has been pointed out that the incidence of lightning in Sri Lanka has also increased from 1998 to 2014 [62]. Considering all these factors, the main point to be concluded is that the margin separating the dry zone and the intermediate-zone has changed slightly.

However, some studies $[21,39,42]$ have shown that there is a decrease in annual rainfall trends in some districts. Nevertheless, this study seems to have generated a slightly opposite opinion. The main reason for this is that the study used raster data (CHIRPS data) generated by taking into account the spatial variability of rainfall, but previous studies used data provided by precipitation stations that did not consider spatial variability. Using one or two rainfall stations for one province or district, it is not very successful to apply those values to the whole district or province. Based on the results of this study, it can be concluded that there is a tendency for an increase in annual rainfall trends in all four climate zones.

With increasing rainfall at both the annual and seasonal level, it is likely that there will be an increased risk of floods in the southern and western provinces in the future. Finally, with the results of this study, the main point that should be brought to the attention of decision-makers is that the eastern and southeastern districts may face severe droughts in the future due to the declining rainfall trend in NEM. Therefore, it is advisable to introduce effective drought and flood management and preparedness measures with special attention to these areas. However, the findings from rainfall trend analysis through CHIRPS data can be used effectively to capture the effect of rainfall on climate change in Sri Lanka.

Author Contributions: Conceptualization, Niranga Alahacoon and Mahesh Edirisinghe; data curation, Niranga Alahacoon; formal analysis Niranga Alahacoon; investigation, Niranga Alahacoon; Methodology, Niranga Alahacoon and Mahesh Edirisinghe; resources, Niranga Alahacoon; Validation, Niranga Alahacoon and Mahesh Edirisinghe; visualization, Niranga Alahacoon and Mahesh Edirisinghe; writing —original draft, Niranga Alahacoon; writing—review and editing, Niranga Alahacoon and Mahesh Edirisinghe. All authors have read and agreed to the published version of the manuscript.

Funding: This research received no external funding.

Institutional Review Board Statement: Not applicable.

Informed Consent Statement: Not applicable.

Data Availability Statement: Daily grided rainfall data (CHIRPS data) are available at Climate Hazards Group InfraRed Precipitation corrected with stations data (https://data.chc.ucsb.edu/ products/CHIRPS-2.0/global_daily/netcdf/p05/ (accessed on 31 December 2020)). Location-specific ground-measured rainfall data are available at the Irrigation Department of Sri Lanka (https: / www. irrigation.gov.lk (accessed on 31 December 2020))

Acknowledgments: The authors are thankful to the Climate Hazard Groups for providing the longterm observatory data (CHIRPS data), and the Irrigation Department of Sri Lanka for providing the relevant ground-measured rainfall data. Assistance and facilities provided by the International Water Management Institute and Department of Physics, University of Colombo are highly acknowledged.

Conflicts of Interest: The authors declare no conflict of interest. 


\section{Appendix A}

Table A1. Mann-Kendall (M-K) test results for annual rainfall at the district level.

\begin{tabular}{cccc}
\hline District & K-Tau & Sen's Slope & $p$-Value \\
\hline Ampara & 0.17 & 8.64 & 0.143 \\
Anuradhapura & 0.34 & 13.91 & 0.009 \\
Badulla & 0.31 & 11.71 & 0.018 \\
Batticaloa & 0.18 & 6.75 & 0.181 \\
Colombo & 0.50 & 30.22 & 0.0001 \\
Galle & 0.44 & 28.51 & 0.001 \\
Gampaha & 0.56 & 28.44 & 0.0001 \\
Hambantota & 0.30 & 7.91 & 0.023 \\
Jaffna & 0.19 & 10.34 & 0.148 \\
Kalutara & 0.51 & 34.85 & 0.000 \\
Kandy & 0.39 & 17.22 & 0.003 \\
Kegalle & 0.50 & 27.20 & 0.000 \\
Kilinochchi & 0.25 & 14.06 & 0.056 \\
Kurunegala & 0.49 & 18.80 & 0.001 \\
Mannar & 0.32 & 16.42 & 0.013 \\
Matale & 0.39 & 15.94 & 0.003 \\
Matara & 0.34 & 23.71 & 0.004 \\
Moneragala & 0.33 & 10.04 & 0.012 \\
Mullaitivu & 0.29 & 14.69 & 0.028 \\
Nuwara Eliya & 0.41 & 15.62 & 0.002 \\
Polonnaruwa & 0.37 & 13.29 & 0.004 \\
Puttalam & 0.40 & 15.29 & 0.002 \\
Ratnapura & 0.51 & 25.48 & 0.000 \\
Trincomalee & 0.26 & 11.45 & 0.044 \\
Vavuniya & 0.34 & 13.62 & 0.010 \\
\hline
\end{tabular}

Table A2. M-K test results for annual rainfall at climate-zone level.

\begin{tabular}{cccc}
\hline Climate Zone & K-Tau & Sen's Slope & $p$-Value \\
\hline Dry & 14.521 & 0.362 & 0.016 \\
Wet & 31.301 & 0.483 & 0.001 \\
Intermediate & 17.270 & 0.396 & 0.009 \\
Semi-Arid & 11.549 & 0.312 & 0.022 \\
\hline
\end{tabular}

Table 3. M-K test results for SWM, NEM, FIM, and SIM rainfall at the district level.

\begin{tabular}{|c|c|c|c|c|c|c|c|c|c|c|c|c|}
\hline \multirow{2}{*}{ District } & \multicolumn{3}{|c|}{ SWM } & \multicolumn{3}{|c|}{ NEM } & \multicolumn{3}{|c|}{ FIM } & \multicolumn{3}{|c|}{ SIM } \\
\hline & K-Tau & $p$-Value & Sen's & K-Tau & $p$-Value & Sen's & K-Tau & $p$-Value & Sen's & K-Tau & $p$-Value & Sen's \\
\hline Ampara & 0.221 & 0.090 & 3.159 & -0.053 & 0.695 & -2.981 & 0.258 & 0.048 & 2.982 & 0.097 & 0.464 & 2.845 \\
\hline Anuradhapura & 0.175 & 0.181 & 3.735 & 0.053 & 0.695 & 1.430 & 0.304 & 0.019 & 4.099 & 0.101 & 0.443 & 2.578 \\
\hline Badulla & 0.129 & 0.326 & 2.667 & -0.094 & 0.475 & -2.848 & 0.281 & 0.031 & 5.312 & 0.147 & 0.261 & 3.144 \\
\hline Batticaloa & 0.166 & 0.205 & 1.698 & -0.044 & 0.748 & -2.583 & 0.249 & 0.056 & 2.106 & 0.055 & 0.682 & 1.403 \\
\hline Colombo & 0.377 & 0.004 & 18.650 & -0.011 & 0.943 & -0.357 & 0.262 & 0.044 & 6.369 & 0.147 & 0.261 & 6.287 \\
\hline Galle & 0.322 & 0.013 & 17.665 & -0.023 & 0.872 & -0.488 & 0.161 & 0.218 & 4.065 & 0.272 & 0.037 & 8.020 \\
\hline Gampaha & 0.377 & 0.004 & 15.782 & 0.002 & 1.000 & 0.000 & 0.299 & 0.021 & 7.244 & 0.097 & 0.464 & 4.628 \\
\hline Hambantota & 0.235 & 0.072 & 4.092 & -0.090 & 0.498 & -3.166 & 0.175 & 0.181 & 2.298 & 0.143 & 0.276 & 2.832 \\
\hline Jaffna & 0.244 & 0.061 & 1.001 & 0.094 & 0.475 & 3.661 & 0.180 & 0.169 & 1.272 & 0.078 & 0.556 & 2.378 \\
\hline Kalutara & 0.364 & 0.005 & 21.943 & -0.060 & 0.665 & -1.137 & 0.253 & 0.042 & 5.967 & 0.235 & 0.067 & 9.779 \\
\hline Kandy & 0.157 & 0.232 & 5.224 & 0.023 & 0.872 & 0.892 & 0.313 & 0.016 & 6.699 & 0.147 & 0.261 & 3.865 \\
\hline Kegalle & 0.285 & 0.028 & 11.381 & 0.009 & 0.957 & 0.052 & 0.345 & 0.008 & 9.395 & 0.106 & 0.422 & 5.155 \\
\hline Kilinochchi & 0.184 & 0.159 & 0.978 & 0.067 & 0.617 & 2.823 & 0.230 & 0.077 & 2.646 & 0.097 & 0.464 & 2.761 \\
\hline Kurunegala & 0.239 & 0.066 & 6.769 & 0.030 & 0.830 & 0.477 & 0.299 & 0.021 & 5.967 & 0.133 & 0.309 & 3.893 \\
\hline Mannar & 0.106 & 0.422 & 2.362 & 0.009 & 0.454 & 2.231 & 0.235 & 0.072 & 3.524 & 0.180 & 0.169 & 5.005 \\
\hline
\end{tabular}


Table 3. Cont.

\begin{tabular}{ccccccccccccc}
\hline \multirow{2}{*}{ District } & \multicolumn{3}{c}{ SWM } & \multicolumn{3}{c}{ NEM } & \multicolumn{3}{c}{ FIM } & \multicolumn{3}{c}{ SIM } \\
\cline { 2 - 13 } & K-Tau & $p$-Value & Sen's & K-Tau & $\boldsymbol{p}$-Value & Sen's & K-Tau & $\boldsymbol{p}$-Value & Sen's & K-Tau & $p$-Value & Sen's \\
\hline Matale & 0.198 & 0.129 & 5.816 & -0.025 & 0.853 & -0.265 & 0.262 & 0.044 & 5.132 & 0.120 & 0.363 & 3.843 \\
Matara & 0.304 & 0.019 & 14.600 & -0.064 & 0.630 & -0.829 & 0.189 & 0.148 & 3.520 & 0.267 & 0.040 & 6.040 \\
Moneragala & 0.193 & 0.139 & 3.051 & -0.076 & 0.568 & -2.137 & 0.272 & 0.037 & 4.446 & 0.166 & 0.205 & 4.146 \\
Mullaitivu & 0.221 & 0.090 & 2.381 & 0.085 & 0.521 & 2.873 & 0.253 & 0.052 & 3.486 & 0.101 & 0.443 & 2.556 \\
Nuwara & 0.120 & 0.363 & 4.352 & 0.041 & 0.762 & 0.312 & 0.299 & 0.021 & 6.786 & 0.129 & 0.326 & 4.274 \\
Eliya & & & & & & & & & & & & \\
Polonnaruwa & 0.184 & 0.159 & 4.765 & 0.044 & 0.748 & 1.092 & 0.267 & 0.040 & 3.370 & 0.078 & 0.556 & 2.964 \\
Puttalam & 0.189 & 0.148 & 4.016 & 0.057 & 0.669 & 0.958 & 0.230 & 0.077 & 4.249 & 0.143 & 0.276 & 3.163 \\
Ratnapura & 0.290 & 0.026 & 10.826 & 0.011 & 0.943 & 0.299 & 0.276 & 0.034 & 6.407 & 0.212 & 0.104 & 6.487 \\
Trincomalee & 0.143 & 0.276 & 2.830 & 0.080 & 0.544 & 3.737 & 0.272 & 0.037 & 2.027 & 0.092 & 0.486 & 1.723 \\
Vavuniya & 0.157 & 0.232 & 3.577 & 0.039 & 0.775 & 0.664 & 0.258 & 0.048 & 3.554 & 0.106 & 0.422 & 3.989 \\
\hline
\end{tabular}

\section{References}

1. Intergovernmental Panel on Climate Change (IPCC). Climate Change 2007-The Physical Science Basis: Working Group; Cambridge University Press: Cambridge, UK, 2007.

2. Intergovernmental Panel on Climate Change (IPCC). Climate Change 2007-Impacts, Adaptation and Vulnerability; Cambridge University Press: Cambridge, UK, 2007.

3. Intergovernmental Panel on Climate Change (IPCC). Climate Change 2013-The Physical Science Basis; Cambridge University Press: Cambridge, UK; New York, NY, USA, 2013.

4. Bureau of Meteorogy; CSIRO. The State of the Climate Report; Australian Government: Canberra, ACT, Australia, 2014.

5. Banholzer, S.; Kossin, J.; Donner, S. The Impact of Climate Change on Natural Disasters. In Reducing Disaster: Early Warning Systems for Climate Change; Singh, A., Zommers, Z., Eds.; Springer: Dordrecht, The Netherlands, 2014. [CrossRef]

6. New, M.; Todd, M.; Hulme, M.; Jones, P. Precipitation measurements and trends in the twentieth century. Int. J. Climatol. 2001, 21, 1899-1922. [CrossRef]

7. $\quad$ Lawrimore, J.H.; Halpert, M.S.; Bell, G.D.; Menne, M.J.; Lyon, B.; Schnell, R.C.; Gleason, K.L.; Easterling, D.R.; Thiaw, W.; Wright, W.J.; et al. Climate assessment for 2000. Bull. Am. Meteorol. Soc. 2001, 82, 1-39. [CrossRef]

8. Brunetti, M.; Maugeri, M.; Monti, F.; Nanni, T. Temperature and precipitation variability in Italy in the last two centuries from homogenised instrumental time series. Int. J. Climatol. 2006, 26, 345-381. [CrossRef]

9. Norrant, C.; Douguedroit, A. Monthly and daily precipitation trends in the Mediterranean (1950-2000). Theor. Appl. Climatol. 2006, 83, 89-106. [CrossRef]

10. Gonzalez-Hidalgo, J.C.; Brunetti, M.; De Lu1s, M. A new tool for monthly precipitation analysis in Spain: MOPREDAS database (monthly precipitation trends December 1945-November 2005). Int. J. Climatol. 2011, 31, 715-731. [CrossRef]

11. Caloiero, T.; Coscarelli, R.; Ferrari, E.; Mancini, M. Precipitation change in Southern Italy linked to global scale oscillation indexes. Nat. Hazards Earth Syst. Sci. 2011, 11, 1683-1694. [CrossRef]

12. Sharma, K.P.; Moore, B.; Vorosmarty, C.J. Anthropogenic, climatic, and hydrologic trends in the Kosi basin, Himalaya. Clim. Chang. 2000, 47, 141-165. [CrossRef]

13. Hamilton, J.P.; Whitelaw, G.S.; Fenech, A. Mean annual temperature and total annual precipitation trends at Canadian biosphere reserves. Environ. Monit. Assess. 2001, 67, 239-275. [CrossRef] [PubMed]

14. Boyles, R.P.; Raman, S. Analysis of climate trends in North Carolina (1949-1998). Environ. Int. 2003, 29, 263-275. [CrossRef]

15. Rao, V.B.; Franchito, S.H.; Santo, C.M.E.; Gan, M. An update on the rainfall characteristics of Brazil: Seasonal variations and trends in 1979-2011. Int. J. Climatol. 2016, 36, 291-302. [CrossRef]

16. Parthasarathy, B.; Kumar, K.R.; Munot, A.A. Homogeneous Indian monsoon rainfall-Variability and prediction. Proc. Indian Acad. Sci. Earth Planet. Sci. 1993, 102, 121-155.

17. Srivatsava, H.N. Decadal trends in climate over India. Mausam 1992, 43, 7-20.

18. Goswami, B.N.; Venugopal, V.; Sengupta, D.; Madhusoodanan, M.S.; Xavier, P.K. Increasing trend of extreme rain events over India in a warming environment. Science 2006, 314, 1442-1445. [CrossRef] [PubMed]

19. Guhathakurta, P.; Rajeevan, M. Trends in the Rainfall Pattern over India; NCC Research Report No 2/2006; National Climate Centre, India Meteorological Department: Delhi, India, 2006; p. 23.

20. Ranagalage, M.; Ratnayake, S.S.; Dissanayake, D.; Kumar, L.; Wickremasinghe, H.; Vidanagama, J.; Cho, H.; Udagedara, S.; Jha K.K.; Simwanda, M.; et al. Spatiotemporal Variation of Urban Heat Islands for Implementing Nature-Based Solutions: A Case Study of Kurunegala, Sri Lanka. ISPRS Int. J. Geo-Inf. 2020, 9, 461. [CrossRef]

21. Nisansala, W.D.S.; Abeysingha, N.S.; Islam, A.; Bandara, A.M.K.R. Recent rainfall trend over Sri Lanka (1987-2017). Int. J. Climatol. 2020, 40, 3417-3435. [CrossRef]

22. Caloiero, T. Analysis of rainfall trend in New Zealand. Environ. Earth Sci. 2015, 73, 6297-6310. [CrossRef] 
23. Shishutosh, B.; Nitin, M.; Ng, A.W.M.; Perera, B.J.C. Rainfall trend and its implications for water resource management within the Yarra River catchment, Australia. Hydrol. Process. 2013, 27, 1727-1738.

24. Naveendrakumar, G.; Vithanage, M.; Kwon, H.H.; Iqbal, M.C.M.; Pathmarajah, S.; Obeysekera, J. Five Decadal Trends in Averages and Extremes of Rainfall and Temperature in Sri Lanka. Adv. Metrol. 2018, 2018. [CrossRef]

25. Clift, P.D.; Plumb, R.A. The Asian Monsoon: Causes, History and Effects; Cambridge University Press: Cambridge, UK, 2008.

26. Rasmussen, E.M.; Carpenter, T.H. The relationship between eastern equatorial Pacific sea surface temperature and rainfall over India and Sri Lanka. Mon. Weather Rev. 1982, 110, 354-384. [CrossRef]

27. Ropelewski, C.F.; Halpert, M.S. Global and regional scale precipitation patterns associated with the El Niño/Southern Oscillation (ENSO). Mon. Weather Rev. 1987, 115, 1606-1626. [CrossRef]

28. Suppiah, R. Spatial and temporal variations in the relationships between the Southern Oscillation phenomenon and the rainfall of Sri Lanka. Int. J. Climatol. 1996, 16, 1391-1407. [CrossRef]

29. Zubair, L.; Siriwardhana, M.; Chandimala, J.; Yahiya, Z. Predictability of Sri Lankan rainfall based on ENSO. Int. J. Climatol. 2008, 28, 91-101. [CrossRef]

30. Geethalakshmi, V.; Yatagai, A.; Palanisamy, K.; Umetsu, C. Impact of ENSO and the Indian Ocean Dipole on the north-east monsoon rainfall of Tamil Nadu State in India. Hydrol. Process. Int. J. 2009, 23, 633-647. [CrossRef]

31. Chandimala, J.; Zubair, L. Predictability of stream flow and rainfall based on ENSO for water resources management in Sri Lanka. J. Hydrol. 2007, 335, 303-312. [CrossRef]

32. Kumar, P.P.; Rajagopalan, B.; Cane, M.A. On the weakening relationship between the Indian Monsoon and ENSO. Science 1999, 284, 2156-2159. [CrossRef]

33. Suppiah, R. Four types of relationships between rainfall and paddy production in Sri Lanka. GeoJournal 1985, 10, 109-118. [CrossRef]

34. Zubair, L. El Niño-Southern Oscillation influences on rice production in Sri Lanka. Int. J. Climatol. 2002, 22, 249-260. [CrossRef]

35. Farmer, B.H. Green Revolution? Technology and Change in Rice-Growing Areas of Tamil Nadu and Sri Lanka; Farmer, B.H., Ed.; MacMillan: London, UK, 1977.

36. Disaster Management Centre. Drought Situation Report_Sri Lanka, 30th May 2017; Ministry of Public Administration and Disaster Management: Colombo, Sri Lanka, 2017.

37. Prasanna, R.P.I.R. Economic costs of drought and farmers' adaptation strategies: Evidence from Sri Lanka. Sri Lanka J. Econ. Res. 2018, 5, 61-79.

38. Somaratne, S.; Dhanapala, A.H. Potential impact of global climate change on forest distribution in Sri Lanka. Water Air Soil Pollut. 1996, 92, 129-135.

39. Bandara, C.M.; Wickramagamage, P. Climate Change and Its Impact on Upper 867 Watershed of the Hill Country of Sri Lanka. In Proceedings of the International Conference on Sustainable Water Resources Management in Changing Environment of the Monsoon Region, Sri Lanka, Colombo, 17-19 November 2004.

40. Kayane, I.; Nakagawa, K.; Edagawa, H.; Bandara, C.M. Hydrological Consequences of Global Warming Revealed by the CenturyLong Climatological Data in Sri Lanka and Southwest India. In Report of Special Research Project on Global Environmental Change 3; University of Tsukuba: Ibaraki, Japan, 1998.

41. Jayawardene, H.K.W.I.; Jayawardena, D.R.; Sonnadara, D.U.J. Interannual variability of 801 precipitation in Sri Lanka. J. Natl. Sci. Found. Sri Lanka 2015, 43, 75-82. [CrossRef]

42. Karunathilaka, K.L.A.A.; Dabare, H.K.V.; Nandalal, K.D.W. Changes in Rainfall in Sri 821 Lanka during 1966-2015. J. Inst. Eng. Sri Lanka 2017, 50, 39-48.

43. De Costa, W.A.J.M. Climate change in Sri Lanka: Myth or reality? Evidence from long-term meteorological data. J. Natl. Sci. Found. Sri Lanka 2008, 36, 63-88. [CrossRef]

44. Katsanos, D.; Retalis, A.; Tymvios, F.; Michaelides, S. Analysis of precipitation extremes based on satellite (CHIRPS) and in situ dataset over Cyprus. Nat. Hazadrs 2016. [CrossRef]

45. Banerjee, A.; Chen, R.; Meadows, M.E.; Singh, R.B.; Mal, S.; Sengupta, D. An Analysis of Long-Term Rainfall Trends and Variability in the Uttarakhand Himalaya Using Google Earth Engine. Remote Sens. 2020, 12, 709. [CrossRef]

46. Gebrechorkos, S.H.; Hülsmann, S.; Bernhofer, C. Long-term trends in rainfall and temperature using high-resolution climate datasets in East Africa. Sci. Rep. 2019, 9, 1-9. [CrossRef] [PubMed]

47. Muthoni, F.K.; Odongo, V.M.; Ochieng, J.; Mugalavai, E.M.; Mourice, S.K.; Hoesche-Zeledon, I.; Mwila, M.; Bekunda, M. Long-term spatial-temporal trends and variability of rainfall over Eastern and Southern Africa. Theor. Appl. Climatol. 2019, 137, 1869-1882. [CrossRef]

48. Wu, W.; Li, Y.; Luo, X.; Zhang, Y.; Ji, X.; Li, X. Performance evaluation of the CHIRPS precipitation dataset and its utility in drought monitoring over Yunnan Province, China. Geomat. Nat. Hazards Risk 2019, 10, 2145-2162. [CrossRef]

49. Funk, C.; Peterson, P.; Landsfeld, M.; Pedreros, D.; Verdin, J.; Shukla, S.; Husak, G.; Rowland, J.; Harrison, L.; Hoell, A.; et al. The climate hazards infrared precipitation with stations-A new environmental record for monitoring extremes. Sci. Data 2015, 2, 1-21. [CrossRef]

50. Dandridge, C.; Lakshmi, V.; Bolten, J.; Srinivasan, R. Evaluation of Satellite-Based Rainfall Estimates in the Lower Mekong River Basin (Southeast Asia). Remote Sens. 2019, 11, 2709. [CrossRef] 
51. Pandey, V.; Srivastava, P.K.; Singh, S.K.; Petropoulos, G.P.; Mall, K.R. Drought Identification and Trend Analysis Using Long-Term CHIRPS Satellite Precipitation Product in Bundelkhand, India. Sustainability 2021, 13, 1042. [CrossRef]

52. Burt, T.P.; Weerasinghe, K.D.N. Rainfall distributions in Sri Lanka in time and space: An analysis based on daily rainfall data. Climate 2014, 2, 242-263. [CrossRef]

53. Zubair, L. El Niño-southern oscillation influences on the Mahaweli streamflow in Sri Lanka. Int. J. Climatol. 2003, 23, 91-102. [CrossRef]

54. Thambyahpillay, G. The rainfall rhythm in Ceylon. Univ. Ceylon Rev. 1954, 12, 223-274.

55. Wickramagamage, P. Seasonality and spatial pattern of rainfall of Sri Lanka: Explanatory factor analysis. Int. J. Climatol. 2010, 30, 1235-1245. [CrossRef]

56. Disaster Management Center. Drought Situation Report—Sri Lanka, 17th May 2018; Ministry of Public Administration and Disaster Management: Colombo, Sri Lanka, 2018.

57. Disaster Management Center. Drought Situation report—Sri Lanka, 26th May 2016; Ministry of Public Administration and Disaster Management: Colombo, Sri Lanka, 2016.

58. Alahacoon, N.; Matheswaran, K.; Pani, P.; Amarnath, G. A Decadal Historical Satellite Data and Rainfall Trend Analysis (2001-2016) for Flood Hazard Mapping in Sri Lanka. Remote Sens. 2018, 10, 448. [CrossRef]

59. Gadgil, A.; Dhorde, A. Temperature trends in twentieth century at Pune, India. Atmos. Environ. 2005, 39, 6550-6556. [CrossRef]

60. Helsel, D.R.; Hirsch, R.M. Statistical Methods in Water Resources; Elsevier Science: Amsterdam, The Netherlands, 1992.

61. Sen, P.K. Estimates of the regression coefficient based on Kendall's tau. J. Am. Stat. Assoc. 1968, 63, 1379-1389. [CrossRef]

62. Maduranga, U.G.D.; Edirisinghe, M.; Gamage, L.V. Annual variation trend of lightning flash activities over Sri Lanka. Int. J. World Sci. News 2018, 114, 256-264. 